\title{
Photosynthesis and Degree of Polymerization of Fructan during Reproductive Growth of Meadow Fescue at two Temperatures and two Photon Flux Densities
}

\author{
CH. LABHART, J. NÖSBERGER, AND C. J. NELSON ${ }^{1}$ \\ Institut für Pflanzenbau, ETH-Zürich, Universitätstr. 2, \\ CH-8092 Zürich, Switzerland
}

Received 15 November 1982

\begin{abstract}
Accumulation of dry weight was measured in plant parts of meadow fescue (Festuca pratensis Huds.) that was grown at $16 / 11^{\circ} \mathrm{C}$ or $26 / 21^{\circ} \mathrm{C}$ and with 20 or $60 \mathrm{nE} \mathrm{cm}^{-2} \mathrm{~s}^{-1}$ photosynthetically active radiation. Plants reached anthesis about 3 weeks later at $16 / 11^{\circ} \mathrm{C}$ than at $26 / 21^{\circ} \mathrm{C}$ and had then a higher proportion of dry weight in inflorescences and less in leaf blades. Growth temperature had little

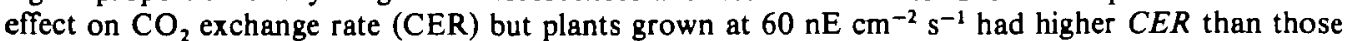
grown at $20 \mathrm{nE} \mathrm{cm}^{-2} \mathrm{~s}^{-1}$.

The concentration of water-soluble carbohydrates (WSC) at similar growth stages was usually higher at $16 / 11^{\circ} \mathrm{C}$ than at $26 / 21^{\circ} \mathrm{C}$. High radiation also led to higher WSC in stem and leaf tissue. Root tissue changed least and WSC did not exceed $10 \%$ of dry weight during the experiment. In all tissues, when WSC was high, the fructans were distributed into a group with a high degree of polymerization (DP) and another with a low DP. The low DP group included sucrose, reducing sugars and fructans up to about 20 units long. An apparent threshold concentration of WSC was necessary for synthesis of the high DP fructans. This concentration was near $12 \%$ for leaf tissue, about $6 \%$ for stem base tissue, and $2.5 \%$ for root tissue. The average apparent DP of the high DP fructan group was 43 to 50 for leaf tissue, 31 to 93 for stem base tissue, and 27 to 31 for roots. These characteristics appeared to be mostly tissue dependent with less effect from temperature and radiation.
\end{abstract}

Key words: Fructans, Meadow fescue; Environmental effects; Dry weight distribution.

\section{INTRODUCTION}

Total nonstructural carbohydrate (TNC) of cool-season perennial grasses consists largely of fructan, a polymer of fructose. The TNC is important for winter survival, for production of new plant tissue after harvest, and during growth periods when assimilate demand exceeds the supply from photosynthesis (Smith, 1972). In addition, forage quality and suitability for preservation of grasses depends on both the concentration and composition of TNC (Kühbauch and Kleeburger, 1975; Kühbauch, 1978). High light intensity and low temperature favours the accumulation of water-soluble carbohydrates in grasses (Deinum, 1966).

Temperature effects on degree of polymerization of fructans of timothy (Phleum pratense L.) at anthesis were investigated by Smith (1968). Similar information is not available for

${ }^{1}$ Current address: Department of Agronomy, University of Missouri, Columbia, U.S.A. 
meadow fescue (Festuca pratensis Huds.), or for species that store short-chain fructans. The objectives of our experiments in growth chambers were to study the influence of photon flux density (PPFD) and temperature during early growth stages on the composition of water-soluble carbohydrates and fructans during reproductive growth.

\section{MATERIALS AND METHODS}

A clone of meadow fescue (Festuca pratensis Huds., cv. Bundy) that had passed the 1977-1978 winter was removed from the field in April. Tillers, consisting of one shoot, roots, and leaves cut to $1.0 \mathrm{~cm}$, were planted in plastic pots that were $12 \mathrm{~cm}$ in diameter and filled with washed perlite. From the 6th day $50 \mathrm{ml}$ of nutrient solution (Hammer, Tibbits, Langhans, and MacFarlane, 1978) was given each morning, with deionized water being added each afternoon to maintain adequate moisture.

Plants were eventually grown under four conditions with light provided by 'Silvana' cool-white fluorescent lamps (CW/VHO, $215 \mathrm{~W} ; 75 \%$ ) and incandescent bulbs (40 W; 25\%):

(1) $26 / 21^{\circ} \mathrm{C}$ (day/night) $60 \mathrm{nE} \mathrm{cm}-2 \mathrm{~s}^{-1}$,

(2) $26 / 21^{\circ} \mathrm{C}$ (day/night) $20 \mathrm{nE} \mathrm{cm}^{-2} \mathrm{~s}^{-1}$,

(3) $16 / 11^{\circ} \mathrm{C}$ (day/night) $60 \mathrm{nE} \mathrm{cm} \mathrm{cm}^{-2} \mathrm{~s}^{-1}$,

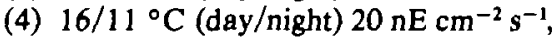

However, for the first $6 \mathrm{~d}$ the plants to be grown at $60 \mathrm{nE} \mathrm{cm}^{-2} \mathrm{~s}^{-1}$ were grown at $24 \mathrm{nE} \mathrm{cm} \mathrm{cm}^{-2} \mathrm{~s}^{-1}$, and for the first $8 \mathrm{~d}$ the plants to be grown at $26 / 21^{\circ} \mathrm{C}$ were grown at $18 / 13^{\circ} \mathrm{C}$. These conditions placed less stress on the plants, allowing them to become acclimated before moving to the experimental treatments. In all cases the photoperiod was $16 \mathrm{~h}$ and relative humidity was $70 \% / 85 \%$ (day/night). Plant material was sampled on six dates, with six replicates per date, in a way that the two growth stages 'panicle emergence' (just before panicle becomes visible above the collar of the flag leaf) and 'anthesis' (anthers visible on all but the two lowest spikelets) were included for each of the four conditions.

Carbon dioxide exchange rate was measured under the same conditions as the plants had been grown using an open system (Winzeler and Nösberger, 1980). Calculation was carried out according to Séstak, Catsky, and Jarvis (1971). Two Philips G 92/2 HPI/T 375 W lamps served as the light source with heat radiation being intercepted by a $7.0 \mathrm{~cm}$ water filter. The lower part of the leaf cuvette consisted of a copper chamber through which water was circulated to control cuvette temperature at $16^{\circ} \mathrm{C}$ or $26^{\circ} \mathrm{C}$.

The harvested tissue was heated for $1 \mathrm{~h}$ at $105^{\circ} \mathrm{C}$ and then dried at $70^{\circ} \mathrm{C}$ for $47 \mathrm{~h}$ for dry matter determination. Dried tissue was ground, stored in sealed bottles at $-18{ }^{\circ} \mathrm{C}$, and then redried for $12 \mathrm{~h}$ at $60^{\circ} \mathrm{C}$ before analysis. A $100 \mathrm{mg}$ sample of plant tissue was shaken with $25 \mathrm{ml} \mathrm{H}_{2} \mathrm{O}$ for $1 \mathrm{~h}$ at room temperature to remove water-soluble carbohydrates and then the solution was filtered through Schleicher and Schuell No. 595 paper. Soluble proteins were precipitated by $1.0 \mathrm{ml}$ of $10 \%$ lead acetate and removed on a Whatman 50 filter paper. Filtrate was reduced to dryness in a rotary evaporator at $60{ }^{\circ} \mathrm{C}$ and then dissolved in $20 \mathrm{ml}$ or $30 \mathrm{ml} \mathrm{H}_{2} \mathrm{O}$. From this solution $1.0 \mathrm{ml}$ was layered onto a $1.5 \mathrm{~cm} \times$ $90 \mathrm{~cm}$ chromatography column filled with Sephadex G-100 gel. Fructans were eluted with $0.2 \mathrm{M} \mathrm{NaCl}$ at a flow rate of $20 \mathrm{ml} \mathrm{h}^{-1}$.

The volume of the gel $\left(V_{1}-V_{0}\right)$ was $84 \mathrm{ml}$ and was sampled in 21 fractions. A series of dextrans (blue dextran, dextran $\mathrm{T40}$, dextran 20, dextran 10, dextran 4) and $\mathrm{K}_{2} \mathrm{CrO}_{4}$ of known molecular weights were used to calibrate the column for molecular weights and degree of polymerization. In every fraction, and in an aliquot of the plant extract containing the water-soluble carbohydrates, the concentration of carbohydrate was measured with an anthrone procedure with the reaction occurring for $15 \mathrm{~min}$ at $100^{\circ} \mathrm{C}$ (Dimler, Schaefer, Wise, and Rist, 1952). Fructose was used as the standard. Photon flux density was measured using a Li-Cor quantum sensor sensitive only to photosynthetically active radiation.

\section{RESULTS}

\section{Dry matter production}

A yield difference was detected $19 \mathrm{~d}$ after planting when plants exposed to either the high PPFD, or to $26 / 21^{\circ} \mathrm{C}$ with the low PPFD, were heavier than those exposed to $16 / 11^{\circ} \mathrm{C}$ and $20 \mathrm{nE} \mathrm{cm} \mathrm{cm}^{-2} \mathrm{~s}^{-1}$ (Table 1). Growth temperature had a greater effect on rate of development than did PPFD. At $26 / 21^{\circ} \mathrm{C}$ the plants reached anthesis about 3 weeks earlier than at $16 / 11^{\circ} \mathrm{C}$, and the plants had lower dry weights. Much of the large weight increase during the post-anthesis period at $26 / 21^{\circ} \mathrm{C}$ occurred because of profuse tillering. 
T A B LE 1. Dry weight per plant of meadow fescue plants grown at two temperatures and two photon flux densities (PPFD)

\begin{tabular}{|c|c|c|c|c|c|c|c|}
\hline \multirow{2}{*}{$\begin{array}{l}\text { Temperature } \\
\left({ }^{\circ} \mathrm{C}\right)\end{array}$} & \multirow{2}{*}{ 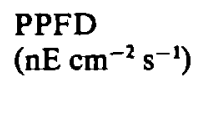 } & \multicolumn{6}{|c|}{ Days after planting (mg dry wt.) } \\
\hline & & 15 & 19 & 26 & 29 & 47 & 50 \\
\hline $26 / 21^{\circ} \mathrm{C}$ & $\begin{array}{l}60 \\
20\end{array}$ & $96^{a}$ & $\begin{array}{l}154^{a} \\
121\end{array}$ & $\begin{array}{l}272 \\
168^{b}\end{array}$ & $310^{b}$ & & $\begin{array}{l}2476 \\
1202\end{array}$ \\
\hline $16 / 11^{\circ} \mathrm{C}$ & $\begin{array}{l}60 \\
20 \\
\text { s.e. }\end{array}$ & - & $\begin{array}{l}115 \\
107 \\
5.3\end{array}$ & $\begin{array}{c}162^{a} \\
154^{a} \\
3 \cdot 4\end{array}$ & & $694^{b}$ & $\begin{array}{c}869 \\
473^{b} \\
81.8\end{array}$ \\
\hline
\end{tabular}

a Panicle emergence, s.e. $=4 \cdot 2$

${ }^{b}$ Anthesis, s.e. $=19.3$

In this and the following tables standard errors (s.e. $n=6$ ) refer to pooled data for all light and temperature treatments.

TABLE 2. Percentage distribution of dry weight of meadow fescue plants grown at two temperatures and two photon flux densities (PPFD)

\begin{tabular}{|c|c|c|c|c|c|c|c|}
\hline \multirow{2}{*}{$\begin{array}{l}\text { Temperature } \\
\left({ }^{\circ} \mathrm{C}\right)\end{array}$} & \multirow{2}{*}{ 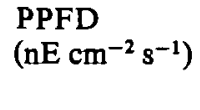 } & \multicolumn{6}{|c|}{ Days after planting ( $\%$ of total dry wt.) } \\
\hline & & 15 & 19 & 26 & 29 & 47 & 50 \\
\hline \multicolumn{8}{|l|}{ Inflorescences } \\
\hline $26 / 21^{\circ} \mathrm{C}$ & 60 & \multirow{3}{*}{$一^{a}$} & $\overline{10}^{0}$ & 28.6 & \multirow[t]{3}{*}{$29 \cdot 3^{b}$} & \multirow{3}{*}{$17.4^{b}$} & $6 \cdot 0$ \\
\hline \multirow{2}{*}{$16 / 11^{\circ} \mathrm{C}$} & 60 & & - & $-a$ & & & $12 \cdot 5$ \\
\hline & 20 & & - & 一a & & & $\begin{array}{r}25.2^{b} \\
0.54\end{array}$ \\
\hline \multicolumn{8}{|l|}{ Leaf blades } \\
\hline \multirow[t]{2}{*}{$26 / 21^{\circ} \mathrm{C}$} & 60 & \multirow{5}{*}{$14 \cdot 9^{a}$} & $12 \cdot 0^{\circ}$ & 9.7 & \multirow[t]{5}{*}{$11 \cdot 3^{6}$} & \multirow{5}{*}{$24 \cdot 0^{b}$} & 39.6 \\
\hline & 20 & & 11.5 & $8 \cdot 5^{b}$ & & & 44.4 \\
\hline \multirow[t]{2}{*}{$16 / 11^{\circ} \mathrm{C}$} & 60 & & 19.4 & $14 \cdot 9^{a}$ & & & $28 \cdot 8$ \\
\hline & 20 & & $18 \cdot 1$ & $12 \cdot 4^{a}$ & & & $13 \cdot 3^{b}$ \\
\hline s.e. ${ }^{a} 0.37 ; \infty 0.83$ & & & 0.42 & 0.35 & & & 0.52 \\
\hline \multicolumn{8}{|l|}{ Stem and sheaths } \\
\hline \multirow[t]{2}{*}{$26 / 21^{\circ} \mathrm{C}$} & 60 & \multirow{5}{*}{$50 \cdot 3^{a}$} & $61.5^{\circ}$ & 45.4 & \multirow[t]{5}{*}{$42 \cdot 6^{b}$} & & $26 \cdot 6$ \\
\hline & 20 & & 51.4 & $49.8^{\circ}$ & & & 24.6 \\
\hline $16 / 11^{\circ} \mathrm{C}$ & 60 & & $45 \cdot 7$ & $57 \cdot 2^{\circ}$ & & $36 \cdot 1^{\circ}$ & 33.0 \\
\hline & 20 & & 48.4 & $63.8^{\circ}$ & & & $45 \cdot 8^{b}$ \\
\hline s.e. ${ }^{8} 0.67 ; \infty 0.84$ & & & 0.68 & 0.79 & & & 0.59 \\
\hline \multicolumn{8}{|l|}{ Roots } \\
\hline $26 / 21^{\circ} \mathrm{C}$ & 60 & \multirow{4}{*}{$33 \cdot 7^{a}$} & $26 \cdot 3^{a}$ & $16 \cdot 1$ & \multirow[t]{4}{*}{$16 \cdot 6^{b}$} & \multirow{4}{*}{$22 \cdot 2^{\circ}$} & 27.6 \\
\hline $16 / 11^{\circ} \mathrm{C}$ & 60 & & 34.8 & $\begin{array}{l}10 \cdot 0 \\
27.7^{a}\end{array}$ & & & $25 \cdot 5$ \\
\hline & 20 & & 33.4 & $24 \cdot 3^{\circ}$ & & & $15 \cdot 5^{b}$ \\
\hline s.e. ${ }^{a} 1 \cdot 10 ; b 0.49$ & & & 0.68 & 1.02 & & & 0.48 \\
\hline
\end{tabular}

${ }^{a}$ Panicle emergence; ${ }^{b}$ Anthesis.

Distribution of dry weight among plant parts was influenced by both temperature and PPFD (Table 2). Plants reached anthesis later at $16 / 11^{\circ} \mathrm{C}$, which tended to allow a greater relative production of leaf tissue. However, at $26 / 21^{\circ} \mathrm{C}$, due to the increasing number of tillers, by the 50th day the percentage of tissue in leaf blades had increased dramatically. 
These new tillers remained vegetative and therefore caused the percentage of tissue as stem to be diluted at later samplings.

\section{$\mathrm{CO}_{2}$ exchange rate}

The CERs of plants grown and measured at $60 \mathrm{nE} \mathrm{cm}^{-2} \mathrm{~s}^{-1}$ were higher than those at 20 $\mathrm{nE} \mathrm{cm}^{-2} \mathrm{~s}^{-1}$ throughout the experimental period (Table 3). Growth temperature had only a small effect on CER. The decrease in CER due to leaf ageing after panicle emergence was expressed to a greater degree at the high PPFD within both temperature regimes. At anthesis CER at the high PPFD was about $25 \%$ higher at $26 / 21^{\circ} \mathrm{C}$ than at $16 / 11^{\circ} \mathrm{C}$.

TABLE 3. Carbon dioxide exchange rate of the second fully-expanded leaf during reproductive growth at two temperatures and two photon fux densities (PPFD)

\begin{tabular}{|c|c|c|c|c|c|c|c|}
\hline \multirow{2}{*}{$\begin{array}{l}\text { Temperature } \\
\left({ }^{\circ} \mathrm{C}\right)\end{array}$} & \multirow{2}{*}{ 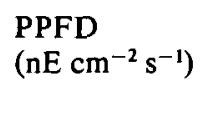 } & \multicolumn{6}{|c|}{ Days after planting (mg CO $2 \mathrm{dm}^{-2} \mathrm{~h}^{-1}$ ) } \\
\hline & & 15 & 19 & 26 & 29 & 47 & 50 \\
\hline \multirow[t]{2}{*}{$26 / 21^{\circ} \mathrm{C}$} & 60 & & $21 \cdot 1^{a}$ & $23 \cdot 3$ & $20 \cdot 1^{b}$ & & $14 \cdot 1$ \\
\hline & 20 & $9.0^{a}$ & 9.9 & $9 \cdot 5^{b}$ & & & 7.8 \\
\hline \multirow[t]{3}{*}{$16 / 11^{\circ} \mathrm{C}$} & 60 & & 17.9 & $20 \cdot 2^{a}$ & & $15 \cdot 6^{b}$ & $12 \cdot 0$ \\
\hline & 20 & & $12 \cdot 5$ & $9 \cdot 7^{a}$ & & & $8 \cdot 7^{b}$ \\
\hline & s.e. & & 0.8 & 1.6 & & & 0.9 \\
\hline
\end{tabular}

${ }^{a}$ Panicle emergence, s.e. $=1 \cdot 3 ;{ }^{b}$ Anthesis, s.e. $=1 \cdot 1$.

\section{Concentration of water-soluble carbohydrates}

Both temperature and PPFD influenced concentration of WSC in all plant parts (Table 4). With high PPFD there was more WSC in leaf blades than with low PPFD at the end of the experiment, especially at the higher temperature. Similar responses to PPFD occurred in the stems and roots. Generally, at similar growth stages the WSC in all plant parts was higher at $16 / 11^{\circ} \mathrm{C}$ than at $26 / 21{ }^{\circ} \mathrm{C}$. Due to the slower rate of development at $16 / 11^{\circ} \mathrm{C}$ (Table 1) the mass of WSC per plant was also higher at this temperature.

During early samplings at $16 / 11^{\circ} \mathrm{C}$, the WSC concentration in all plant parts decreased indicating that the concentration at $0 \mathrm{~d}$ was high and that the plants had not yet met their carbohydrate needs through photosynthesis. Concentrations of WSC in leaf blade and stem tissue tended to increase following panicle emergence except for the $16 / 11^{\circ} \mathrm{C}, 20 \mathrm{nE} \mathrm{cm}-2$ $\mathrm{s}^{-1}$ treatments suggesting that CER was exceeding growth needs. Root tissue had a small variation in WSC concentration throughout the experimental period. In addition, the concentration of WSC in roots did not exceed $10 \%$ despite the fact that concentrations in leaf blades and stems were considerably higher.

\section{Degree of polymerization of fructans}

When concentrations of WSC in all tissues were high, fructans eluted from the column in a bimodial distribution with few fructans being eluted with an apparent DP of about 20 (Fig. 1). Subsequent analysis of hydrolysed fractions using glucose oxidase and an arseno-molybdate reducing group test showed the high DP fraction to be long-chain fructans, whereas analysis of the low DP fractions on Bio-Gel P2 showed them to be a homologous series of up to at least a DP of 9 . Leaf blade tissue from plants grown at $16 / 11^{\circ} \mathrm{C}$ always had fructans with an apparent DP greater than 20 , but that from plants grown at $26 / 21^{\circ} \mathrm{C}$ had fructans of DP 
T A B LE 4. Concentration of water-soluble carbohydrates during reproductive growth at two temperatures and two photon flux densittes (PPFD)

\begin{tabular}{|c|c|c|c|c|c|c|c|}
\hline \multirow{2}{*}{$\begin{array}{l}\text { Temperature } \\
\left({ }^{\circ} \mathrm{C}\right)\end{array}$} & \multirow{2}{*}{ 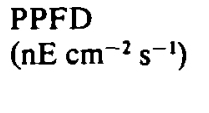 } & \multicolumn{6}{|c|}{ Days after planting ( $\%$ dry matter) } \\
\hline & & 15 & 19 & 26 & 29 & 47 & 50 \\
\hline \multicolumn{8}{|l|}{ Leaf blades } \\
\hline \multirow[t]{2}{*}{$26 / 21^{\circ} \mathrm{C}$} & 60 & & $7 \cdot 7^{a}$ & 7.99 & $11 \cdot 18^{b}$ & & $13 \cdot 85$ \\
\hline & 20 & $5 \cdot 90^{a}$ & $7 \cdot 33$ & $8.75^{b}$ & & & 5.07 \\
\hline \multirow[t]{2}{*}{$16 / 11^{\circ} \mathrm{C}$} & 60 & & $19 \cdot 27$ & $15 \cdot 38^{a}$ & & $23 \cdot 56^{b}$ & 22.65 \\
\hline & 20 & & $18 \cdot 60$ & $14 \cdot 19^{a}$ & & & $12 \cdot 66^{b}$ \\
\hline s.e. ${ }^{a} 0.93 ;{ }^{b} 0.83$ & & & 0.75 & 0.85 & & & 0.65 \\
\hline \multicolumn{8}{|l|}{ Stems and sheaths } \\
\hline \multirow[t]{2}{*}{$26 / 21^{\circ} \mathrm{C}$} & 60 & & $6 \cdot 54^{a}$ & $5 \cdot 41$ & $5 \cdot 95^{b}$ & & $19 \cdot 17$ \\
\hline & 20 & $8 \cdot 40^{a}$ & 4.69 & $6 \cdot 40^{b}$ & & & $7 \cdot 59$ \\
\hline \multirow[t]{2}{*}{$16 / 11^{\circ} \mathrm{C}$} & 60 & & $22 \cdot 28$ & $12 \cdot 00^{\circ}$ & & $15 \cdot 09^{b}$ & $16 \cdot 86$ \\
\hline & 20 & & 20.49 & $12 \cdot 30^{a}$ & & & $13 \cdot 74^{b}$ \\
\hline s.e. ${ }^{a} 0.75 ; \infty 0.05$ & & & 0.55 & 0.63 & & & 0.47 \\
\hline \multicolumn{8}{|l|}{ Roots } \\
\hline \multirow{2}{*}{$26 / 21^{\circ} \mathrm{C}$} & 60 & & $3 \cdot 62^{a}$ & 2.42 & $3 \cdot 00^{b}$ & & $5 \cdot 17$ \\
\hline & 20 & $3 \cdot 54^{a}$ & $2 \cdot 29$ & $3 \cdot 58^{b}$ & & & $2 \cdot 39$ \\
\hline \multirow[t]{2}{*}{$16 / 11^{\circ} \mathrm{C}$} & 60 & & 9.87 & $6 \cdot 30^{a}$ & & $8 \cdot 06^{b}$ & 7.51 \\
\hline & 20 & & 7.85 & $6 \cdot 89^{a}$ & & & $7 \cdot 56^{b}$ \\
\hline s.e. ${ }^{a} 0 \cdot 28 ; 0.20$ & & & 0.32 & $0 \cdot 26$ & & & $0 \cdot 34$ \\
\hline
\end{tabular}

${ }^{a}$ Panicle emergence; ${ }^{b}$ Anthesis.

greater than 20 only with the high PPFD at $50 \mathrm{~d}$. Furthermore, the concentration of the low DP fraction in leaf blade tissue remained relatively constant when plants were grown at $16 / 11^{\circ} \mathrm{C}$ even though the concentration of the high DP fraction changed markedly. At

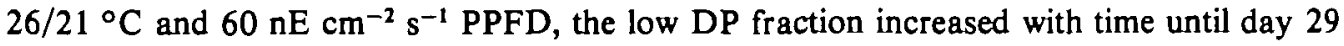
with no high DP fraction being evident. By day 50 a high DP fraction occurred even though the low DP fraction remained similar to day 29. This suggested that a threshold concentration was necessary for the low DP fraction before accumulation of the high DP fraction of fructan begins. Apparently at $20 \mathrm{nE} \mathrm{cm} \mathrm{cm}^{-2} \mathrm{~s}^{-1}$ this threshold was not reached as no high DP fructans were detected. The decrease in WSC from day 19 to day 26 at $16 / 11^{\circ} \mathrm{C}$ (Table 4) was associated mainly with a decrease in high DP fructans (Fig. 1).

Similar to leaf blade tissue at $26 / 21^{\circ} \mathrm{C}$, the content of low DP fructans in stems showed the largest increase with time, and high DP fructans were predominant only at $60 \mathrm{nE} \mathrm{cm} \mathrm{cm}^{-2} \mathrm{~s}^{-1}$ (Fig. 2). Before panicle emergence on day 26 at $16 / 11^{\circ} \mathrm{C}$, the concentration of WSC was decreasing (Table 4) and WSC consisted mainly of high DP fructans with a mean apparent DP of 43 and little low DP fructan or sugars (Fig. 2). As WSC continued to decrease to day 26 (Table 4) the high DP fraction decreased in concentration with little if any change in average DP. At the end of the experimental period the longest fructans were found in tissue grown at low PPFD and at $16 / 11^{\circ} \mathrm{C}$ where average apparent DP was 93 . At the same temperature and $60 \mathrm{nE} \mathrm{cm}^{-2} \mathrm{~s}^{-1}$ the apparent DP was 59 , and at $26 / 21^{\circ} \mathrm{C}$ it was only 36 . The high DP fructan at $26 / 21^{\circ} \mathrm{C}$ was associated with a larger low DP fraction than that at $16 / 11^{\circ} \mathrm{C}$.

Despite the fact that the roots had a relatively low concentration of WSC, there was almost always high DP fructan present (Fig. 3). This fraction in roots had an average DP of 27-31 and showed less variation due to temperature, PPFD, or growth stage than in other tissues. 

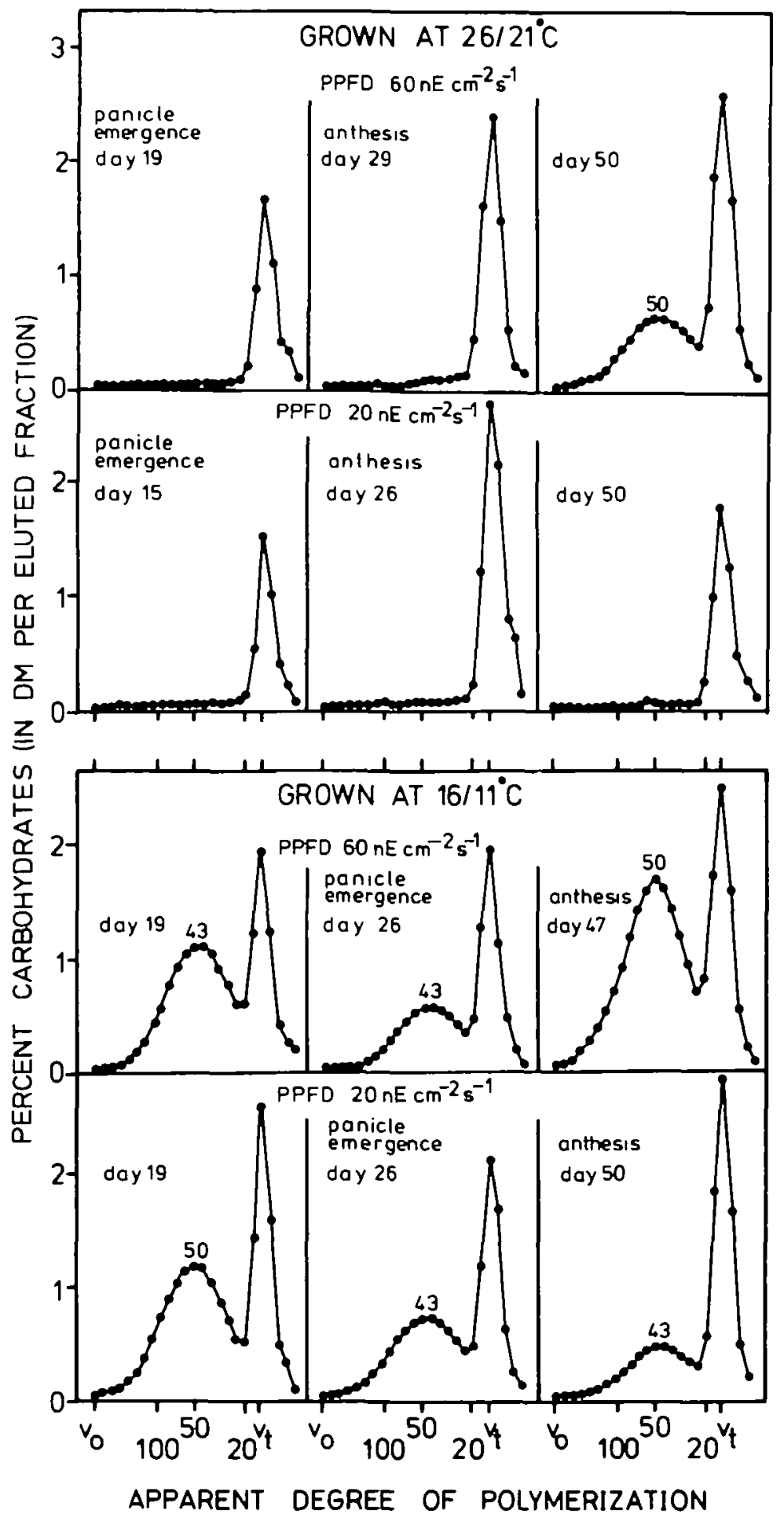

FIO. 1. Influence of growth temperature, photon flux density (PPFD), and growth stage on apparent degree of polymerization (DP) of water-soluble carbohydrates in leaf blade tissue. Numbers above peaks indicate average DP of the high DP fraction. 


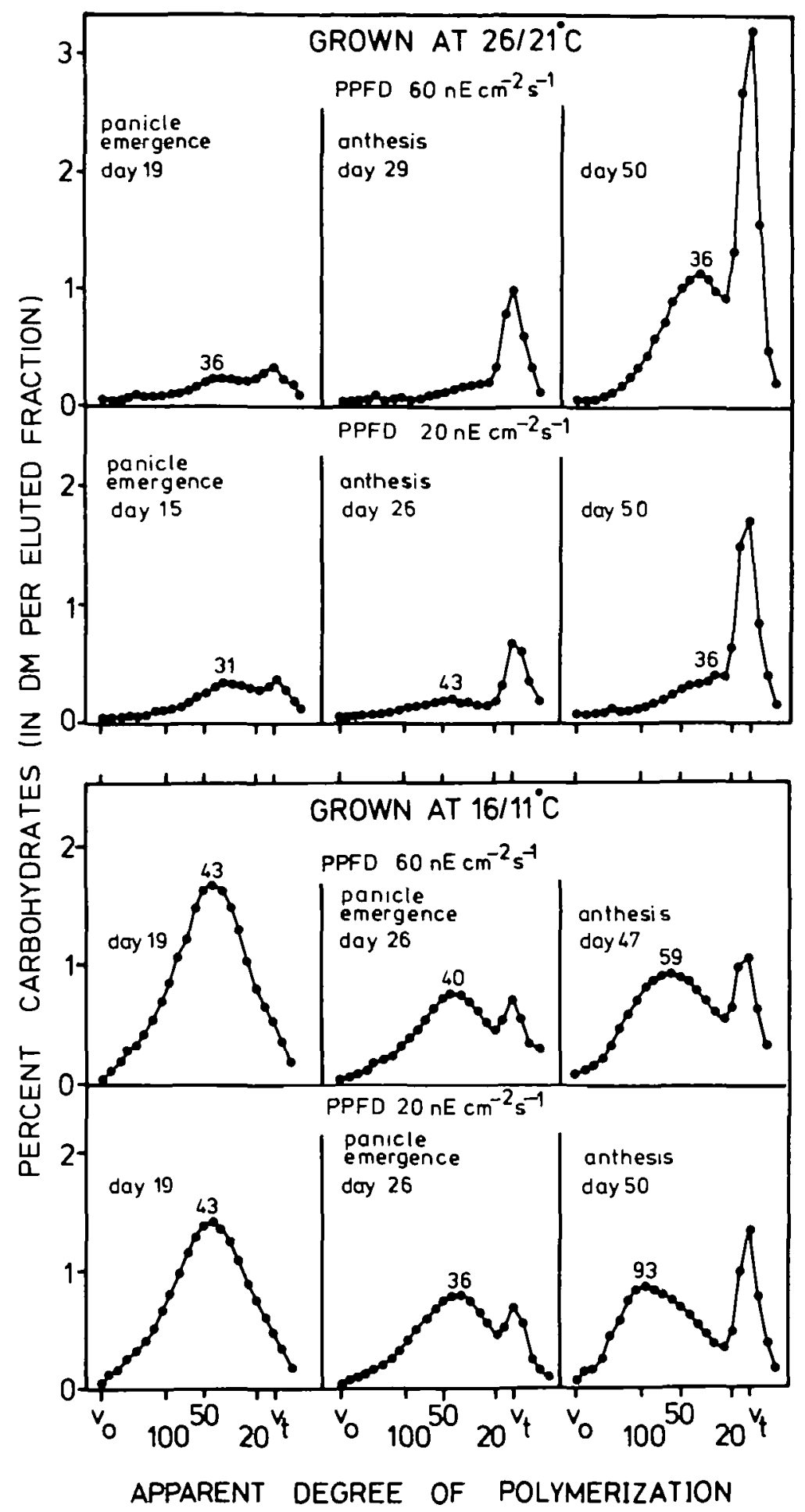

FIa. 2. Influence of growth temperature, photon flux density (PPFD), and growth stage on apparent degree of polymerization (DP) of water-soluble carbohydrates in stem tissue. Numbers above peaks indicate average DP of the high DP fraction. 


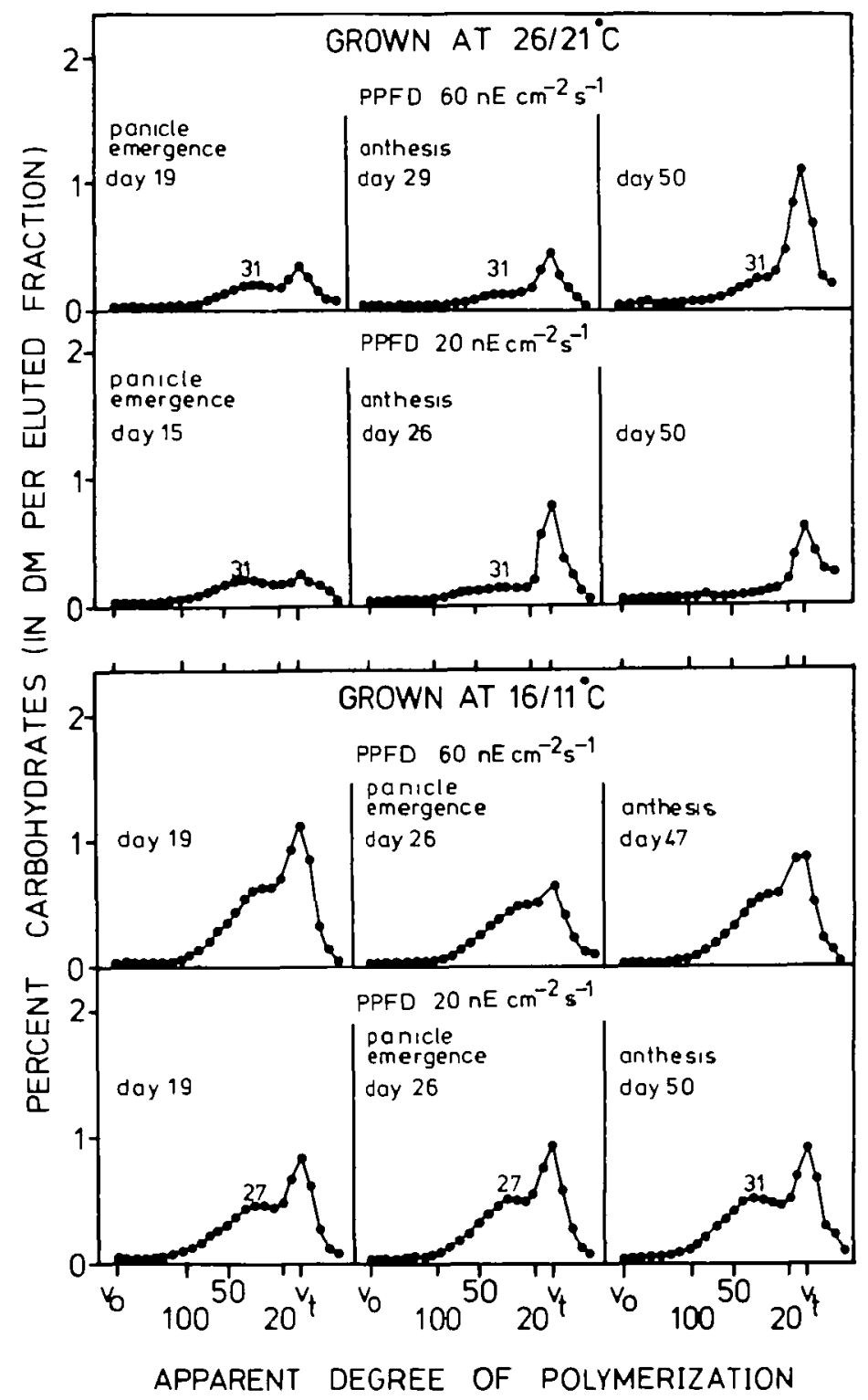

FIG. 3. Infiuence of growth temperature, photon flux density (PPFD), and growth stage on apparent degree of polymerization (DP) of water-soluble carbohydrates in root tissue. Numbers above peaks indicate average DP of the high DP fraction.

\section{DISCUSSION}

At $16 / 11^{\circ} \mathrm{C}$ the concentration of WSC was reduced prior to panicle emergence in all plant parts. Apparently, at this temperature, demand for assimilates for growth of reproductive tillers was supplied by altered distribution of assimilates. Growth rate at $16 / 11^{\circ} \mathrm{C}$ was slower than at $26 / 21^{\circ} \mathrm{C}$ while CER was similar, allowing plants to store more WSC, giving higher concentrations at the lower temperature (Brown, Blaser, and Fontenot, 1963; Smith, 1977).

In all cases at $26 / 21^{\circ} \mathrm{C}$ at either panicle emergence or anthesis, WSC concentration was 
highest in leaf blades followed by stems, with roots being lowest in concentration and with least variation with time. These results are in agreement with those of Frey and Nösberger (1980) who reported that the influence of PPFD on TNC of red clover (Trifolium pratense L.) decreased from leaf blades to the roots. Jones and Nelson (1979) reported that WSC was lower in root tips of tall fescue (Festuca arundinacea Schreb.), and that respiration rate was higher than in leaf blades.

Composition of WSC of all plant parts was strongly influenced by temperature. In contrast to timothy (Phleum pratense L.) (Kühbauch, 1974), a species that accumulates a high DP fructan (Grotelueschen and Smith, 1968), leaf blades of meadow fescue had fructans of intermediate DP that eluted between sucrose and the high DP fraction. Minimal concentrations of fructan occurred at an apparent DP of about 20 when both fractions were present. There appeared to be a threshold or minimal concentration of low DP fructans and sugars that had to be achieved before accumulation of high DP fructans began. Further, this concentration was tissue specific in that it was about $12 \%$ of dry weight in leaf blades, and apparently independent of growth stage, temperature conditions, or PPFD. When concentrations of WSC in leaf blades were above $12 \%$ the average apparent DP of the high DP fructan fraction was 43 to 50 with little effect due to WSC concentration.

Minimal concentration for accumulation of high DP fructans in root tissue was about $2.5 \%$, and the high DP fraction averaged only 27 to 31 units when the fraction was clearly present. Similar to leaf tissue, a range of fructans occurred in roots between the low and high DP peaks with the minimal concentration occurring at about $\mathrm{DP}=20$.

The concentration of WSC also influenced the distribution of fructan DPs in stem tissue, but the pattern was less clear. At $26 / 21^{\circ} \mathrm{C}$ the minimal WSC concentration for accumulation of high DP fructans appeared to be about $6 \%$, but this value cannot be estimated at $16 / 11^{\circ} \mathrm{C}$ because WSC always exceeded $12 \%$. There were fructans present between the low and high DP peaks with minimum concentration of fructan at an apparent DP of about 20. Before panicle emergence on day 19 and when the WSC concentration was decreasing, there was not a distinct peak for the low DP fraction at $16 / 11^{\circ} \mathrm{C}$ (Fig. 2). Rather the two peaks appeared as one with an average apparent $\mathrm{DP}=43$. Perhaps at this stage the stem was acting as a strong source, and quickly converted high DP fructans to sucrose and low DP forms (Pollock and Jones, 1979). Considering all treatments, the high DP fraction in stem tissue had an average apparent DP that ranged from 31-93 with no pattern that was consistent with increasing or decreasing WSC concentration. This was also found by Pollock (1982) in Dactylis glomerata L. Pollock and Jones (1979) reported that DPs of fructans of meadow fescue were highest during times of synthesis and fell rapidly during periods of breakdown. This differs from the results of Mino, Shimada, and Yamamoto (1978) with timothy. They found DP remained relatively constant as fructan decreased during early regrowth. Smith (1967) found DP of fructans of stem bases of timothy decreased then increased as water-soluble carbohydrate decreased and then increased during spring growth in the field. During the same periods bromegrass (Bromus inermis L.) decreased and increased in water-soluble carbohydrate, but did not change in DP.

Growth conditions influenced WSC concentration of plant parts, which in turn had an influence on composition of the fructan present. Most previous work has been on timothy, a species that accumulates high DP fructan with few fructans of DP 5-20 (Kühbauch, 1974). Further, Smith (1968) reported that WSC concentration in leaf blades of timothy was lower at high temperatures, whereas DP of the fructans was also lower, a finding that is not consistent with our data on meadow fescue, a species that stores a lower DP fructan. Smith (1972) classified several grass species according to fructan composition based on DP, but it is clear that they also differ in fructan metabolism. Before general principles can be developed 
regarding functions and dynamics of fructans in grasses, these subtle differences between species will need to be more clearly understood.

\section{ACKNOWLEDGEMENTS}

We thank Mrs. A. Allenbach for growing the plants and Mrs. U. Aleksic and Mrs. M. Bocksch for technical assistance. This work has been supported by a grant from the Swiss Federal Institute of Technology.

\section{LITERATURE CITED}

Brown, R. H., BLASER, R. E., and Fontenot, J. P., 1963. Digestibility of fall grown Kentucky 31 fescue. Agronomy Journal, 55, 321-4.

DeInum, B., 1966. Climatic conditions and nutrient contents of forage crops. Mededeelingen van de Landbouwhoogeschool Wageningen, 66-11, 1-91.

Dimler, R. J., Schaefer, W. C., WISE, C. S., and Rist, C. E., 1952. Quantitative paper chromatography of D-Glucose and its oligosaccharides. Analytical Chemistry, 24, 1411-14.

FreY, F., and NösBerger, J., 1980. Influence of constant and changing radiation and plant age on percentage of total non-structural carbohydrates and crude protein in Trifolium pratense L. Zeitschrift für Acker- und Pflanzenbau, 149, 367-75.

GroteluesCHEN, R. D., and SMTTH, D., 1968. Carbohydrates in grasses. III. Estimations of the degree of polymerization of the fructans in the stem bases of timothy and bromegrass near seed maturity. Crop Science, 8, 210-12.

Hammer, P. A., Tibitts, T. W., Langhans, R. W., and MacFarlane, J. C., 1978. Base-line growth studies of 'Grand Rapids' lettuce in controlled environment. Journal of the American Society of Horticultural Science, 103, 649-55.

JoNES, R. J., and Nelson, C. J., 1979. Respiration and concentration of water soluble carbohydrate in plant parts of contrasting tall fescue genotypes. Crop Science, 19, 367-72.

KUHBAUCH, W., 1974. Content, degree of polymerization and structure of fructosan in different plant parts of timothy grass (Phleum pratense L.) Zeltschrif für Pflanzenphysiologie, 74, 121-9.

- 1978. The nonstructural carbohydrates in grasses of temperate climate zones, their variability and microbial use. Landwirtschaftliche Forschung, 31, 251-68.

- and KLeEburger, A., 1975. Bacterial decomposition of grass-fructosan of different degree of polymerization. Journal of the Brittsh Grassland Society, 30, 223-7.

Mino, Y., Shimada, A., and Yamamoto, S., 1978. Effect of cutting height on the carbohydrate metabolism in the haplocorm of timothy (Phleum pratense L.) Journal of Japanese Society of Grassland Sclence, 24, 34-9.

Pollock, C. J., 1982. Patterns of turnover of fructans in leaves of Dactylls glomerata L. New Phytologist, 90, 645-50.

— and JONES, T., 1979. Seasonal patterns of fructan metabolism in forage grasses. Ibid. 83, 9-15.

Séstak, Z., CATsky, J., and Jarvis, P. G., (Eds) 1971. Plant photosynthetic production. Manual of methods. W. Junk, N. V., Publishers, The Hague.

SMrTH, A. E., 1977. Influence of temperature on tall fescue forage quality and culm base carbohydrates. Agronomy Journal, 69, 745-7.

SMrTH, D., 1967. Carbohydrates in grasses. II. Sugar and fructosan composition of the stem bases of bromegrass and timothy at several growth stages, and in different plants parts at anthesis. Crop Science, 7, 62-7.

- 1968. Carbohydrates in grasses. IV. Influence of temperature on the sugar and fructosan composition of timothy plant parts at anthesis. Ibid. 8, 331-4.

- 1972. Carbohydrate reserves of grasses. In Blology and utllization of grasses. Academic Press, N.Y., Pp. 318-33.

WINZELER, H., and NOSBERGER, J., 1980. Carbon dioxide exchange of spring-wheat in relation to age and photon-flux density at different growth temperatures. Annals of Botany, 46, 685-93. 